\title{
EFFECTS OF GLACIATION ON METHANE-HYDRATE STABILITY
}

\author{
by
}

Douglas R. MacAyeal and Dean R. Lindstrom

(Department of the Geophysical Sciences, University of Chicago, 5734 South Ellis Avenue, Chicago, IL 60637, U.S.A.)

\section{ABSTRACT}

Temperature and pressure changes within subglacial sediments caused by deglaciation favor a phase change from methane hydrate to methane gas. If released to the atmosphere, this gas could have contributed significantly to the increased atmospheric methane concentration during interglacial periods. Using a numerical reconstruction of sediment temperatures and ice-sheet loads, the total sediment volume in the Eurasian Arctic that is subject to this phase change is estimated to be $2.8 \times 10^{14} \mathrm{~m}^{3}$.

\section{INTRODUCTION}

Ice cores from Antarctica and Greenland suggest that atmospheric methane concentration at glacial times is approximately half that at interglacial times (Raynaud and others, 1988; Stauffer and others, 1988). These fluctuations have an important relationship with climate because atmospheric methane is a greenhouse gas and has an effect on global temperature which is comparable to that of $\mathrm{CO}_{2}$ (Donner and Ramanathan, 1980). Methane flux to the atmosphere from terrestrial and aquatic sources primarily controls atmospheric methane concentration. The interglacial rise in atmospheric methane thus signifies the operation of methane sources that are extinguished during glacial times. High-latitude freshwater wetland areas constitute one such methane source (Raynaud and others, 1988). Here we discuss another possible methane source that involves the stability of methane hydrate stored within subglacial sediments (Kvenvolden, 1988; MacDonald, unpublished).

Our goal is to demonstrate the plausibility of methane-hydrate dissociation as a means of increasing atmospheric methane concentration during periods of the Holocene. To do this, we reconstruct past pressure and temperature conditions in the sediments below the Eurasian ice sheet and estimate the sediment volume which crossed the hydrate/gas phase boundary as a result of deglaciation. The hydrate density within this sediment ultimately determines how much methane could have been released to the atmosphere. If it was comparable to estimates of present-day hydrate occurrences, then methane-hydrate dissociation could have been comparable to other Holocene methane sources.

\section{ATMOSPHERIC METHANE BUDGET}

The balance between methane sources and sinks determines the atmospheric methane burden $b$ (Cicerone and Oremland, 1988). Methanogenesis within carbon-rich sediments and methane produced by microorganisms that proliferate within aquatic sediments, soils, and animal gastrointestinal tracts constitute the dominant sources. Oxidation by reaction with the $\mathrm{OH}$ radical in the atmosphere constitutes the dominant sink and is proportional to $b$. Balance implies:

$$
b=\tau Q
$$

where $\tau$ is the residence time $(9.6 \pm 1.5$ years; Cicerone and Oremland, 1988), and $Q$ is the scurce flux $\left(\mathrm{k}_{\mathrm{o}} \mathrm{a}^{-1}\right)$.
Changes in $\tau$ over the glacial cycle cannot be ruled out. The effect of atmospheric warming at the onset of interglacials, for example would favor a decrease of $\tau$ (Raynaud and others, 1988). This change would decrease $b$ during interglacials if all other effects were held constant. The interglacial increase of $b$ thus implies an increase of $Q$ by a factor of approximately 2 . Assuming $\tau$ constant, $Q$ would increase from approximately $101 \pm 20 \times 10^{9} \mathrm{~kg} \mathrm{a}^{-1}$ at glacial times to approximately $184 \pm 37 \times 10^{9} \mathrm{~kg} \mathrm{a}^{-1}$ at preindustrial interglacial times. These flux estimates assume that atmospheric methane concentration varies from approximately $340 \mathrm{ppbv}$ to $620 \mathrm{ppbv}$ over the glacial cycle (Raynaud and others, 1988).

Studies of the present-day atmospheric methane budget suggest that more than one source could have contributed to the interglacial rise of atmospheric methane (Cicerone and Oremland, 1988). As mentioned previously, the increase of freshwater wetland area is one such source. The breakdown of methane hydrate in carbon-rich subglacial sediments is the additional source we evaluate here.

\section{HOW GLACIATION AFFECTS METHANE HYDRATE STABILITY}

Methane hydrate is a nonvolatile compound containing $\mathrm{CH}_{4}$ and $\mathrm{H}_{2} \mathrm{O}$ which is stable in high-pressure, low-temperature sediments. It is commonly found in the interstitial pore space of sediments containing organic carbon under conditions defined by the inequality (an approximation adapted from figure 1 of Kvenvolden, 1988):

$$
\log _{10} P \geqslant 1.43+\left(3.37 \times 10^{-2}\right) T
$$

where $P$ is the geostatic pressure measured in bars ( 1 bar $=$ $10^{5} \mathrm{~Pa}$ ), and $T$ is the sediment temperature measured in ${ }^{\circ} \mathrm{C}$. Ice sheets, particularly those which extended across the organic-rich sediments of the Eurasian continental shelves, could affect the sediment volume in which methane hydrate is stable in three important ways. First, glaciostatic loading of the sea bed (and hydrostatic loading where the sea bed is depressed isostatically by ice) increases $P$. Secondly, icesheet incursion into otherwise subaqueous environments can permit significant cooling of the sediments below the ice, if the ice is grounded and has a frozen base. Thirdly, sealevel lowering due to ice-sheet build-up elsewhere in the world can expose otherwise subaqueous sediments to cold atmospheric temperatures, also permitting significant cooling of the sediments.

Deglaciation after a period of hydrate build-up causes unfavorable $P$ and $T$ conditions for hydrate stability in upper portions of the sediment column. The rate of hydrate dissociation would depend on the rates of thermal equilibration and isostatic rebound. The effect of deglaciation on hydrate stability within a typical sediment column beneath the Eurasian ice sheet is shown in Figure 1.

Kvenvolden (1988) suggests that $10^{15}$ to $10^{18} \mathrm{~kg}$ of carbon is presently distributed as methane hydrate worldwide, and that much of this inventory is located in submarine permafrost of the Arctic continental shelves. Submarine permafrost can form only as a result of glaciation, either by direct ice incursion, or by associated 

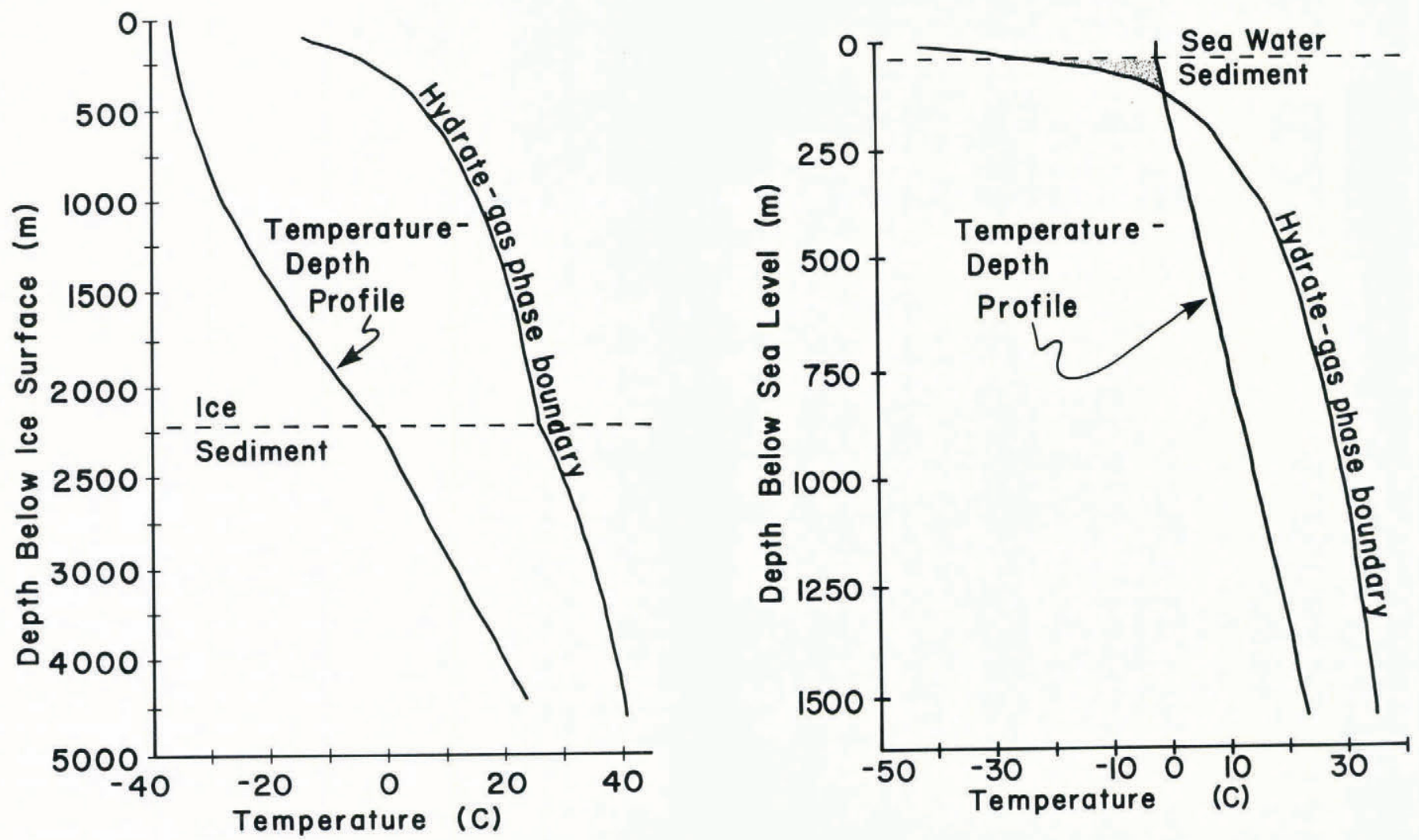

Fig. 1. Methane hydrate phase boundary and geothermal profiles for glacial conditions (left) and interglacial conditions (right). The geothermal profiles are solutions to the coupled ice/sediment heat transfer equations for the continental-shelf location (denoted by a star) in Figure 2. As shown on the left, glaciation tends to push near-surface sediments across the phase boundary to the region where hydrate formation is possible. On deglaciation, isostatic rebound and gradual warming of the sediment move the near-surface sediments back across the phase boundary. This movement can lead to spontaneous methane discharge into the atmosphere if hydrates had accumulated within the sediments during the glacial period.

sea-level lowering. The continental shelves of the Eurasian Arctic are now thought to have been covered by ice at the last glacial maximum (Grosval'd, 1988). These regions thus could have contained hydrate-bearing submarine permafrost just prior to deglaciation.

\section{ESTIMATE OF HYDRATE-STABLE SEDIMENT VOLUME CHANGES}

We estimate the change in hydrate-stable sediment volume between glacial and interglacial conditions by reconstructing past $P$ and $T$ conditions below the Eurasian ice sheet using a numerical ice-sheet/sediment model (Lindstrom, unpublished; Lindstrom and MacAyeal, 1989). This model computed the ice thickness for both floating and grounded ice, areal ice-sheet coverage, and the ice/sediment temperature profile by solving the mass continuity, stress balance, and heat transfer equations. Surface temperatures and snow accumulation rates specified as model input, which indirectly determine the ice loading and temperature of the basal sediments, were extrapolated from present-day values by considering the effect of reduced atmospheric $\mathrm{CO}_{2}$ level at the last glacial maximum (Lindstrom and MacAyeal, 1989). The model was run holding surface temperature and accumulation fixed until an equilibrium was established. The ice-sheet thickness and temperature of the ice/sediment interface so reconstructed are displayed in Figure 2. Interglacial conditions were estimated by assuming that the temperature profile is presently in steady state with current ocean or air temperatures, and that transient temperature variations induced by the deglaciation have dissipated.

Our estimate of the change in hydrate-stable sediment volume of the Eurasian continental shelves between glacial and interglacial periods is $2.8 \times 10^{14} \mathrm{~m}^{3}$. This estimate represents an upper bound because our reconstruction of the ice-sheet coverage and thickness across the continental shelves corresponds with maximal glacial loadings determined from independent geologic observations (Grosval'd, 1988). Our ice-sheet reconstruction (Lindstrom, unpublished) displays extensive grounded ice-sheet coverage over the Laptev and East Siberian seas; and this coverage is currently debatable.

The sediment volume which crosses the stability boundary in $P-T$ space is typically located within the upper $200 \mathrm{~m}$ of the sediment column. The time scale for thermal equilibration over this range of sediment depth is approximately 350 years and is short compared to the time scale for isostatic rebound (approximately $5000 \mathrm{a}$ ). Isostatic rebound is thus likely to have determined the rate of hydrate dissociation and methane flux into the atmosphere after deglaciation.

\section{POTENTIAL AS AN ATMOSPHERIC METHANE SOURCE}

The atmospheric effect of the above hydrate stability change cannot be determined quantitatively because the past density of methane hydrate within subglacial sediments is not known. We can establish, however, the importance of methane-hydrate breakdown in relation to other methane sources by considering estimates of this density used in other studies (Revelle, 1983).

Observations of total organic carbon content in presentday continental slope muds suggest that an upper bound on methane-hydrate density in Arctic continental-shelf sediments is $2.2 \mathrm{~kg} \mathrm{~m}^{-3}$ (Revelle, 1983). Using this estimate, methane released to the atmosphere as result of deglaciation of the Eurasian continental shelves is $6.2 \times 10^{14} \mathrm{~kg}$.

If this release was distributed evenly over the 5000 years (the isostatic rebound time scale) immediately following the collapse of the Eurasian ice sheet, the increase of $Q$ during this period would have been $132 \times 10^{9} \mathrm{~kg} \mathrm{a}^{-1}$; 


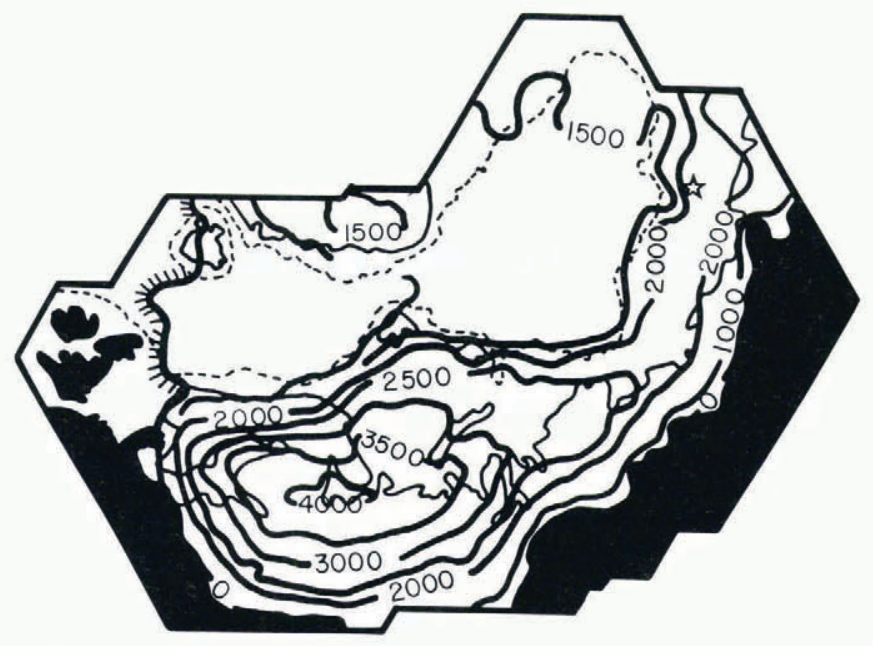

\section{CONCLUSION}

Our reconstruction of past sediment temperature and pressure conditions in regions covered by the Eurasian ice sheet indicates that a significant sediment volume became unfavorable to methane hydrate stability following deglaciation. Methane gas released by hydrate breakdown thus could have contributed to the elevated atmospheric methane concentration of the Holocene. While we are unable to quantify this contribution, our analysis suggests that it cannot be ruled out.

To test this hypothesis further, it is necessary to: (1) establish higher temporal resolution of past atmospheric methane fluctuations, and (2) develop means to evaluate past methanogenesis within sediments, soils and wetlands. The value of higher temporal resolution would be to differentiate between fast and slow methane release mechanisms. It is estimated here that the time scale for hydrate breakdown is approximately 5000 years. More rapid methane concentration changes thus could not be attributable to this source mechanism alone. The value of a means to evaluate past methanogenesis would be to estimate the methane-hydrate density in formerly subglacial sediments.

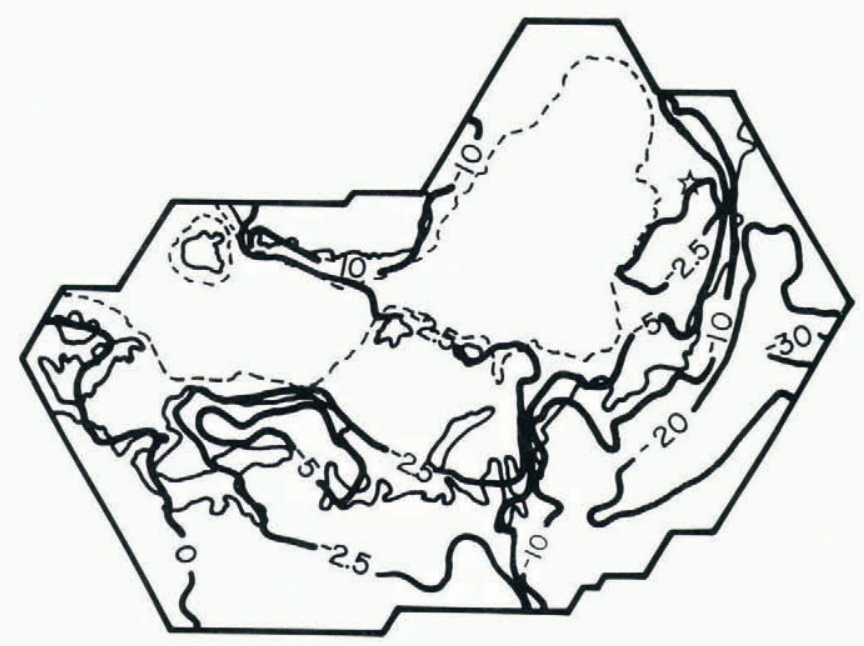

\section{REFERENCES}

Cicerone, R.J. and R.S. Oremland. 1988. Biogeochemical aspects of atmospheric methane. Global Biogeochemical Cycles, 2(4), 299-327.

Donner, L. and V. Ramanathan. 1980. Methane and nitrous oxide: their effects on the terrestrial climate. J. Atmos. Sci., 37, 119-124.

Grosval'd, M.G. 1988. Oledeneniye antarkticheskogo tipa v Severnom polusharii (na puti k novoy global'noy lednikovog teorii [Antarctic-style ice sheet in the Northern Hemisphere (toward a new global glacial theory)]. Materialy Glyatsiologicheskikh Issledovaniy, 63, $3-25$.

Kvenvolden, K.A. 1988. Methane hydrates and global climate. Global Biogeochmical Cycles, 2(3), 221-229.

Lindstrom, D.R. Unpublished. A study of the Eurasian ice sheet using a combined ground ice flow-ice shelf numerical model. (Ph.D. dissertation, University of Chicago, 1989.)

Fig. 2. (upper) Map of ice-sheet thickness (m) and areal coverage used to reconstruct $P$-conditions within subglacial sediments at the last glacial maximum (Lindstrom, unpublished). (lower) Map of ice-sediment interface temperatures (C) used to reconstruct $T$-conditions within subglacial sediments at the last glacial maximum. The open star denotes the location associated with the geothermal profiles plotted in Figure 1.

and this would have caused atmospheric methane concentration to increase by a factor of 2.3. This increase would not have been likely to persist through the entire Holocene without additional methane sources because hydrate dissociation would have eventually tapered off.

Lindstrom, D.R. and D.R. MacAyeal. 1989. Scandinavian, Siberian, and Arctic Ocean glaciation: effect of Holocene atmospheric $\mathrm{CO}_{2}$ variations. Science, 245, 628-631.

MacDonald, G.J. In press. Role of methane clathrates in past and future climates. Climatic Change.

Raynaud, D., J. Chappellaz, J.M. Barnola, Y.S. Korotkevich, and C. Lorius. 1988. Climatic and $\mathrm{CH}_{4}$ cycle implications of glacial-interglacial $\mathrm{CH}_{4}$ change in the Vostok ice core. Nature, 333(6174), 655-657.

Revelle, R.R. 1983. Methane hydrates in continental slope sediments and increasing atmospheric carbon dioxide. In Changing climates. National Research Council (U.S.). Carbon Dioxide Assessment Committee. Washington, DC, National Academy Press, 252-261.

Stauffer, B., E. Lochbronner, H. Oeschger, and J. Schwander. 1988. Methane concentration in the glacial atmosphere was only half that of the preindustrial Holocene. Nature, 332(6167), 812-814. 